\title{
Research on the English Teaching and Autonomous Learning Based on Multimedia Platform and Smart Classroom System
}

\author{
Wang Pingxiao \\ General Education College, Jinhua Polytechnic, Jinhua 321007, Zhejiang, China \\ sd_jxyz@foxmail.com
}

\begin{abstract}
With the development of technology and the popularization of computer media, information technology is playing a more and more important role in foreign language teaching. In this paper, the author analyzes the English teaching and autonomous learning based on multimedia platform and smart classroom system. Intelligent classroom is a wireless ubiquitous network access environment, students can use wireless terminals for interconnection, and student could carry out group discussions and cooperative learning according to the needs of learning. The multimedia classroom provides a more authentic language environment for English teaching. In the teaching process, it can better stimulate students' interest and participation in learning, make independent learning really possible. Through the analysis of English autonomous learning based on multimedia platform, the author puts forward the related English learning strategies.
\end{abstract}

Keywords: Multimedia platform, Smart classroom, English teaching, Autonomous learning

\section{Introduction}

Twenty-first Century is an era of internationalization and information, domestic and international economic and social development will advance at a higher speed. English, as an important tool to absorb and spread the world civilization achievements, opening to the outside world and stimulating the economy, there will be a special and important role in the new century [1]. With the introduction of a new theory of foreign language teaching, especially in recent years due to the rapid development of multimedia technology and information technology, and gradually mature, the traditional college English teaching mode has been hitherto unknown impact and challenge, new technology brings a revolution for the foreign language teaching, also exposed some drawbacks of the traditional teaching mode. Forcing teachers to change ideas, to try new teaching experience [2-3]. The teaching reform is the use of advanced modern educational technology, to promote the English teaching based on information technology, pay more attention to cultivating students' independence and autonomy, and vigorously promote the universal application of information technology in the teaching process, promote the integration of information technology and curriculum, teachers gradually realize the presentation of teaching content, students the learning way, teaching methods and teacherstudent interaction mode change, give full play to the advantages of information technology to provide rich and colorful education environment and strong learning tool for students' learning and development.

Traditional classroom gives the impression that there are desks and chairs, blackboard, podium and other equipment [4]. With the development of electronic technology, electronic audio-visual equipment production and its application in a traditional classroom, the emergence of new forms of electronic classroom, start with the sound amplification equipment, projector, slide, film and television equipment. The advent of the computer, especially the emergence of multimedia technology, the multimedia 
computer can better show the pictures and information. The application of computer multimedia technology in the field of education, the emergence of a new classroom form as Multimedia classroom. More and more electronic equipments are used in the classroom, and more and more teachers are required to improve their operating ability in the teaching process [5]. The equipment of the independence between the teachers' difficulties in operation and its coordination function of each device and connection, it will increase the teachers and teaching staff's work load, which also affect the practical application of these devices in the classroom. With the development of technology and the popularization of computer media, information technology is playing a more and more important role in foreign language teaching. The rise of information technology, we provide a relatively traditional teaching environment more authentic language operating environment, knowledge representation, creation of authentic language environment, broaden the way for students to obtain knowledge, better able to stimulate students' interest in learning and participation in the teaching process, the autonomous learning is really possible.

\section{Multimedia Platform and Intelligent Classroom}

\subsection{Multimedia Platform}

The people of the autonomous learning ability of the twenty-first Century social demands unprecedented increase, science and technology will be on an unprecedented scale rapid development, human scientific knowledge will be hitherto unknown speed increasing, the huge increase in knowledge make people acquire knowledge and skills in school is increasingly limited and outdated, which requires people in and out of school. In order to keep up with the trend of the times, the need to constantly expand their knowledge and skills through learning to improve themselves, realize the value of life[6]. Information technology has penetrated into all levels of society, the field, it makes the whole society from the lifestyle, learning methods, working methods to the mode of production, even the way of thinking have a comprehensive change. The continuous progress and wide application of information technology have brought great impact on education. On the one hand, the Internet and multimedia technology as the core of information technology has become an important tool for teaching and learning; on the other hand, in the era of knowledge economy, information literacy has become an important basis for scientific literacy. Information technology is a new form of modern education and teaching, and an important symbol of modernization of education [7-8].

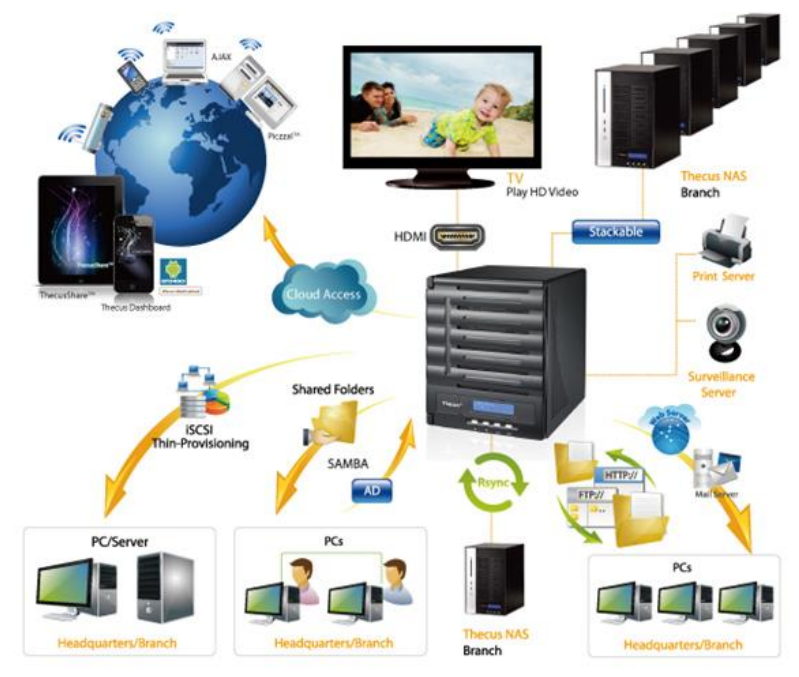

Figure 1. Multimedia Education Platform 
The video of classroom teaching is a broader concept than the notes, teacher's blackboard writing and demonstration lectures, live video and audio and other teaching related line activities can be recorded and playback. Students can use it to review the contents of the class or to learn missed courses. Intelligent classroom environment is a wireless internet access environment in the pan, students can use wireless internet terminal, can discuss in group and cooperative learning based on learning needs, learning terminal can interact with the display terminal for connection, can also interact with remote learners or experts, to facilitate individual learning within the classroom, cooperation distance learning and individual learning or outside the classroom. Introduce the concept of interactive space in the smart classroom, a classroom space of ordinary reinforced interface as a teacher and remote education system, in this space, teachers can get rid of shackles of keyboard and mouse, monitor, and voice, gestures and body language and other traditional teaching experience with remote students interactive. The boundaries of classroom education and distance education are broken, and teachers can teach both live and remote students. Future classroom design is a forward-looking field of educational technology, at present, at home and abroad have been a lot of exploratory research.

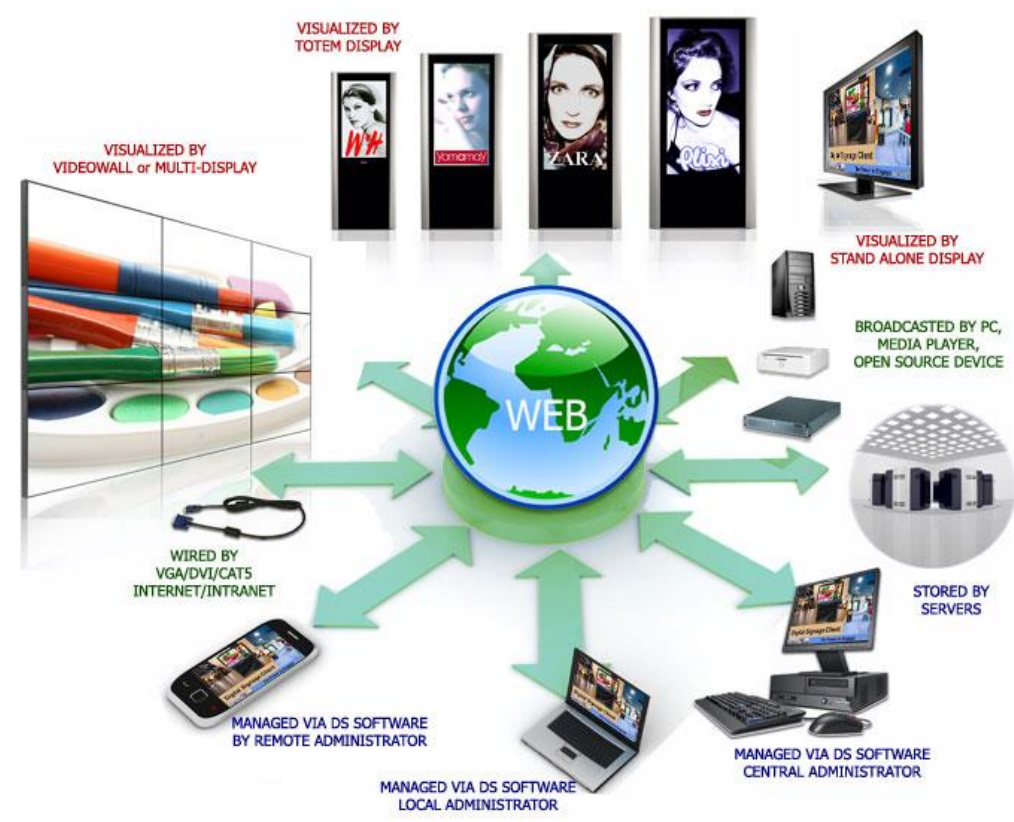

Figure 2. Multimedia Visual Education Equipment

\subsection{Intelligent Classroom}

Smart classroom, is a convenient equipment for audio-visual classroom, computer, projector, whiteboard, such as sound and light, electrical equipment control and operation to access resources seamlessly and teachers engaged in teaching and learning activities, and can adapt to many types of learning including remote teaching, to the nature of human interactive features, enhanced classroom implementation rely on intelligent space technology. What is known about the smart classroom at home and abroad there is a big difference, most of the foreign universities especially in the United States, the more equipped with computer and projection (LCD and optical), DVD, VCR and other video equipment, sound equipment and control equipment in the classroom called smart classroom, the classroom at home are called multimedia the classroom. In addition some domestic middle school have a whiteboard (multimedia classrooms with interactive 
function projection called smart classroom), and also began to have this type of smart classroom equipment began more and more of the primary and middle schools.

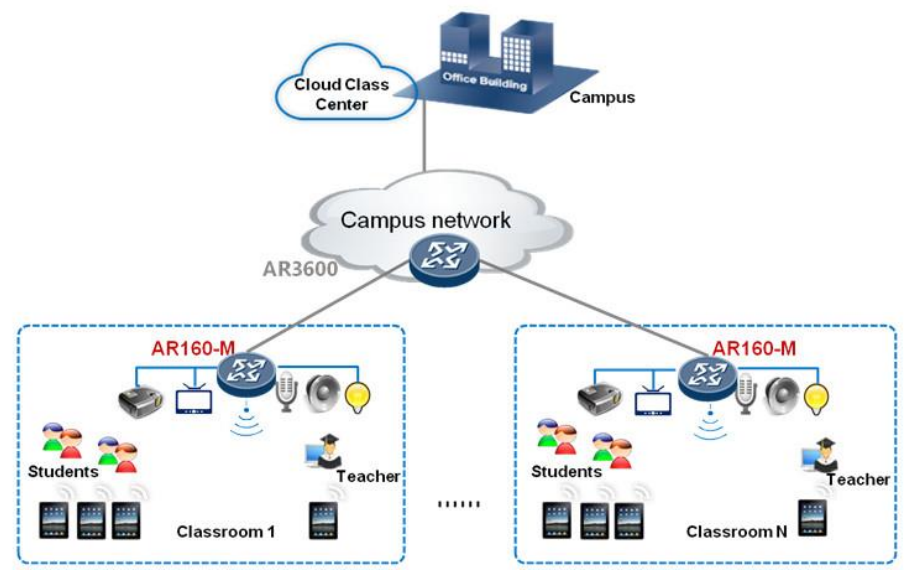

Figure 3. Intelligent Classroom System Framework

The emergence of a situation that often the traditional classroom: students are busy writing content from teachers, and have no time to think carefully about the content itself, which is obviously the efficiency of classroom learning is bad. The DEBBIE project at DePauw University developed a system for this problem. This system has installed a network of tablet computer in each classroom desks and the platform, the teacher writing on the blackboard through the tablet computer pen on the podium, by the support of the software will be distributed to the handwriting tablet computer for each student, where such information can be together with the students themselves writing are recorded together, to avoid duplication of labor of each student copied the teacher writing on the blackboard.

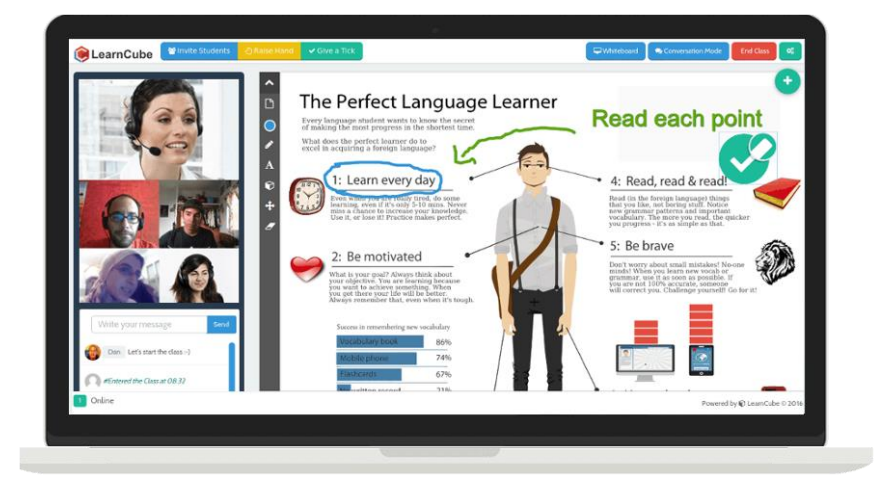

Figure 4. Intelligent Teaching

The current research on intelligent classroom at home and abroad mainly focus on the research of smart classroom technology, the research of intelligent classroom advantages and disadvantages and application effect of the intelligent classroom implement several function research and future research aspects: in the classroom to achieve intelligent classroom technology, with new technology is introduced, and the classroom design and technology the selection of equipment and functions, pay more attention to the user, application of smart classroom technology more advanced, intelligent and emphasizes the interaction, such as the pan in the introduction of the network technology, make the classroom become more concise, but also conducive to teaching and learning in the classroom of ubiquitous learning, interactive whiteboard technology the teachers, learners can use on the whiteboard and resources more convenient interaction, and can record real- 
time interactive process The application of intelligent record system not only solves the problem of traditional classroom teaching, but also can be combined with video conferencing system to achieve good interaction and sharing of resources with remote learners. Currently intelligent classroom types include three types:

1) The first is based on hardware technology, like many foreign universities and some domestic enterprises will be the education informationization equipment equipped with multimedia computer, computer network, LCD projector, AV video display system, multimedia classroom equipment such as PA system called smart classroom,

2) The second is intelligent classroom software technology based on the realization of the smart classroom of this type is mainly by means of virtual intelligent classroom software based on the formation of the network to realize, can be achieved on the learning support, providing a variety of resources and learning form, group communication and cooperation means, such as Classroom 2000, NASA classroom of the future plan;

3) The third is the comprehensive advantages of the former two, both hardware technical support, and with the help of integrated control in the software system of intelligent hardware technology, and on the learning of intelligent tracking and recording, but also can realize the reality of classroom and the virtual classroom (for distance learners) and interactive information exchange group between.

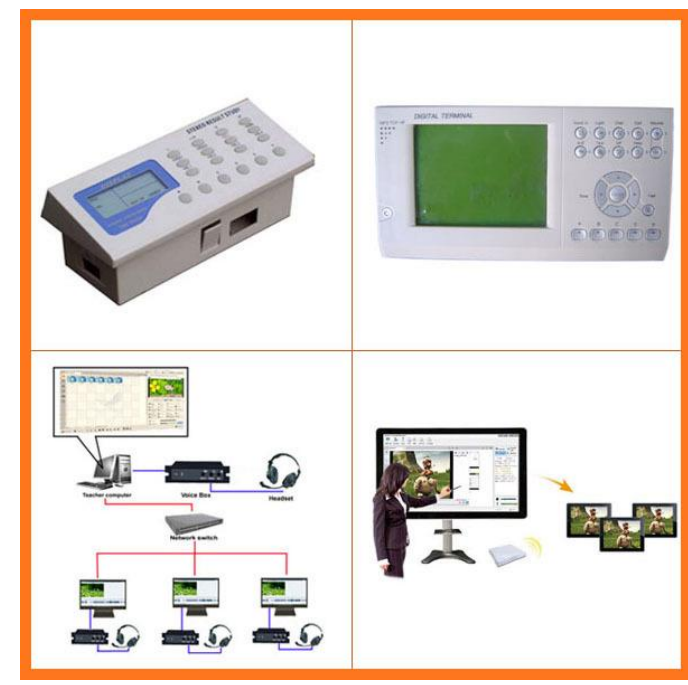

Figure 5. Intelligent Classroom Equipment

\section{English Autonomous Learning Based on Multimedia Platform}

\subsection{English Autonomous Learning Strategies}

The teaching strategy is the key stage to achieve the goal of teaching, involving many aspects of teaching strategies, teaching strategies should be based on teaching theory, teaching content, teaching should not only conform to the objective requirements, but also suitable for the characteristics of the teaching object, but also consider the necessity and feasibility in the specific teaching situation in. We analyze the selection and application of College English autonomous learning strategies from two aspects: universal strategy and specific strategy. General strategies are applicable to all kinds of class teaching strategies, regardless of listening and speaking, reading or writing, or even review the organization of teaching cannot do without teachers; teachers need to adopt different ways to motivate students, as the main part of interactive activities between teachers and students; teaching 
behavior is not any classroom questioning avoid. We will discuss the universality strategy from the aspects of organization strategy, incentive strategy and questioning strategy.

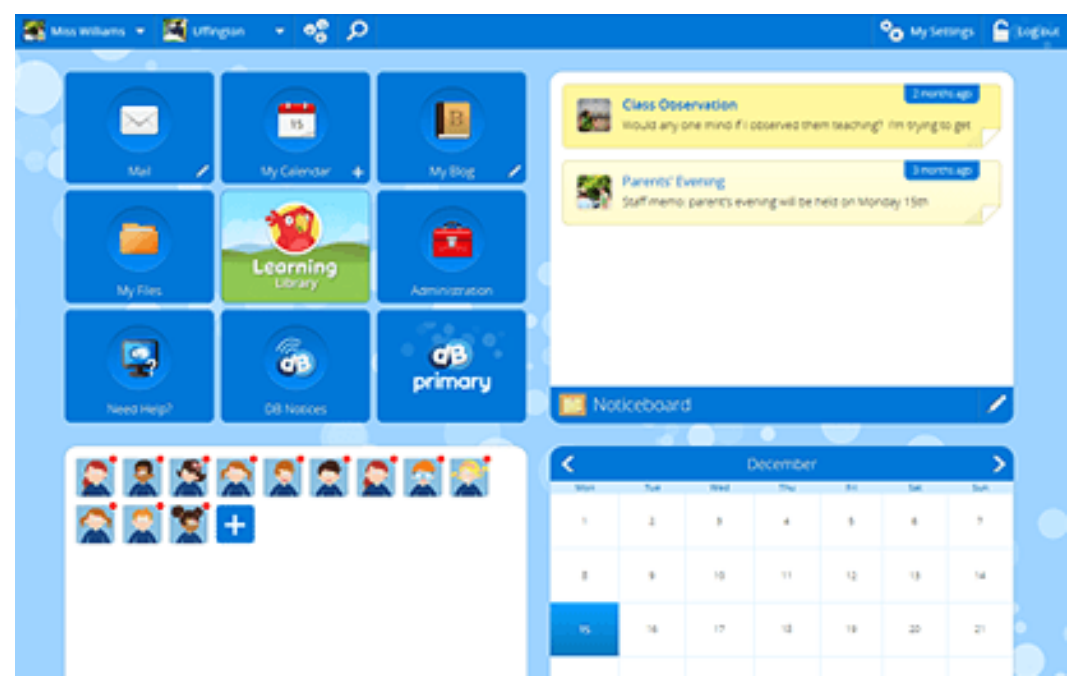

Figure 6. The Online English Learning Platform

\section{(1)Organization strategy}

Classroom organization is one of the main factors for successful completion of teaching tasks. No effective organization of teachers, any activities will not play the due effect. Teachers need to master certain methods and skills, reasonable arrangements for classroom activities, effective understanding of classroom problems, to ensure the smooth conduct of classroom teaching. The important task of teachers in class is to create an environment conducive to students' Autonomous learning". With the development of modern foreign language teaching theory, people have a new understanding of language learning and language teaching. Teachers in the teaching, with the pre class preparation of teaching courseware, through text, images, video, animation and sound different ways of presentation, the teaching focus, to provide extensive information and sufficient language input in the limited teaching time, expanding knowledge, greatly increase the capacity of classroom teaching, so that students in a variety of sensory stimulation "so as to enhance memory, improve the learning effect.

\section{(2)Incentive strategy}

Research shows that the main factors affecting two language acquisition motivation accounted for $33 \%$. The so-called motive is to have definite purpose for a kind of activity and make certain efforts to achieve the purpose. Although many students can realize the importance of learning English well, but because of the lack of comprehensive, intrinsic, deep motivation, usually do not work hard, English learning is not too high requirements. Motivation is closely related to the effect of foreign language learning. Therefore, how to cultivate and stimulate college English learning motivation is an important task for teachers.

\section{(3)Questioning strategy}

Questioning is one of the most common strategies in classroom teaching and the most influential teaching art. As long as students understand the psychological needs of mystery, curiosity and desire to explore will urge students to explore. The enthusiasm and initiative of students to explore learning, often from the situation in question. Through the creation of the problem situation, there is a cognitive conflict between the teaching content, the actual life and the students' seeking knowledge. Answer the questions, as a form of discourse in College English class the most common, can strengthen the communication between teachers and students, to stimulate students' learning motivation, control the teaching process, it has a great effect on language acquisition. 


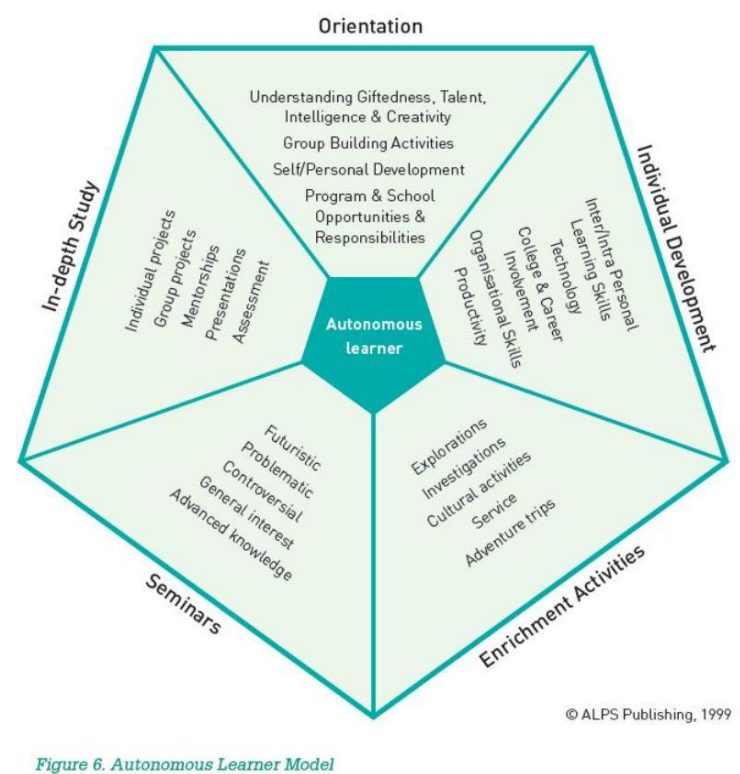

Figure 7. English Autonomous Learning Strategies

Interest is the most realistic and active component in learning motivation. Students interested in learning, it will induce students desire for knowledge, resulting in great enthusiasm for learning. Teachers should make full use of the advantages of information technology to attract students attention, so that students into the learning task, in order to stimulate students interest in learning. Positive classroom environment can stimulate and maintain students' interest in learning, promote students' Autonomous learning. The creation of classroom environment here is not only a physical environment suitable for students to study, but also a learning atmosphere suitable for students' autonomous learning. Although students' learning environment is an external factor that affects students' learning, it can stimulate students' learning motivation. Positive classroom environment, can make students interested in the whole learning process, and actively participate in the learning process, which is an important feature of independent learning.

\subsection{The Influence of Information Technology on College English Teaching}

In the process of teaching, modern information technology represented in the integration of a variety of media information transmission and the characteristics of integration, interactivity, openness, situational and intelligence can provide intelligent teaching resources, teaching process, teaching for nonlinear multi information organization technology supporting a full range of will have a profound impact on the traditional education idea, teaching mode, teaching method, teaching environment and teaching organization. Embodied in the following three aspects:

(1) Provide a variety of cognitive tools and rich learning resources. Such as the use of word processing, graphics, image processing, information integration tools, let the student carry on restructuring of the curriculum, learning content creation, the course of study can not only enable students to acquire knowledge, but also can help students to construct knowledge. A new cognitive tool under the condition of modern information technology compared with the traditional cognitive tool is open, inquiry based on the use of these tools to change the knowledge acquisition and construction way, can not only broaden the scope of the students' cognition, but also can improve the learner's information gathering skills, organizational skills, creative skills, stimulate students' creative thinking the create learners explore and collaborative atmosphere. 
(2) Creating a good learning situation. Using the comprehensive processing ability of a variety of media figure words sound animation and video information of the modern information technology has, through a variety of media information organically, realize sound, visual and vivid expression effect. With the development of modern communication technology, multimedia technology and network communication technology, English news program, online English courses, such as the Internet, began a large number of applications in education, people can get from a broader approach than the traditional classroom, English teachers more than general university more authentic English learning resources. Good learning situations that help students discover problems and ask questions.

(3) Create conditions for the implementation of various learning strategies. Learning strategies refer to learners' understanding of learning tasks, learning methods and regulation of learning process. Different learners have different learning strategies. Modern information technology can provide according to the cognitive characteristics and learning styles of learners of different students choose their preferred learning strategies and opportunities, multimedia and network technology, interactivity, openness and information organization of the hyperlink structure and other characteristics, can provide conditions for teachers to organize the teaching of creative materials, but also make students free choice learning content to become a reality.

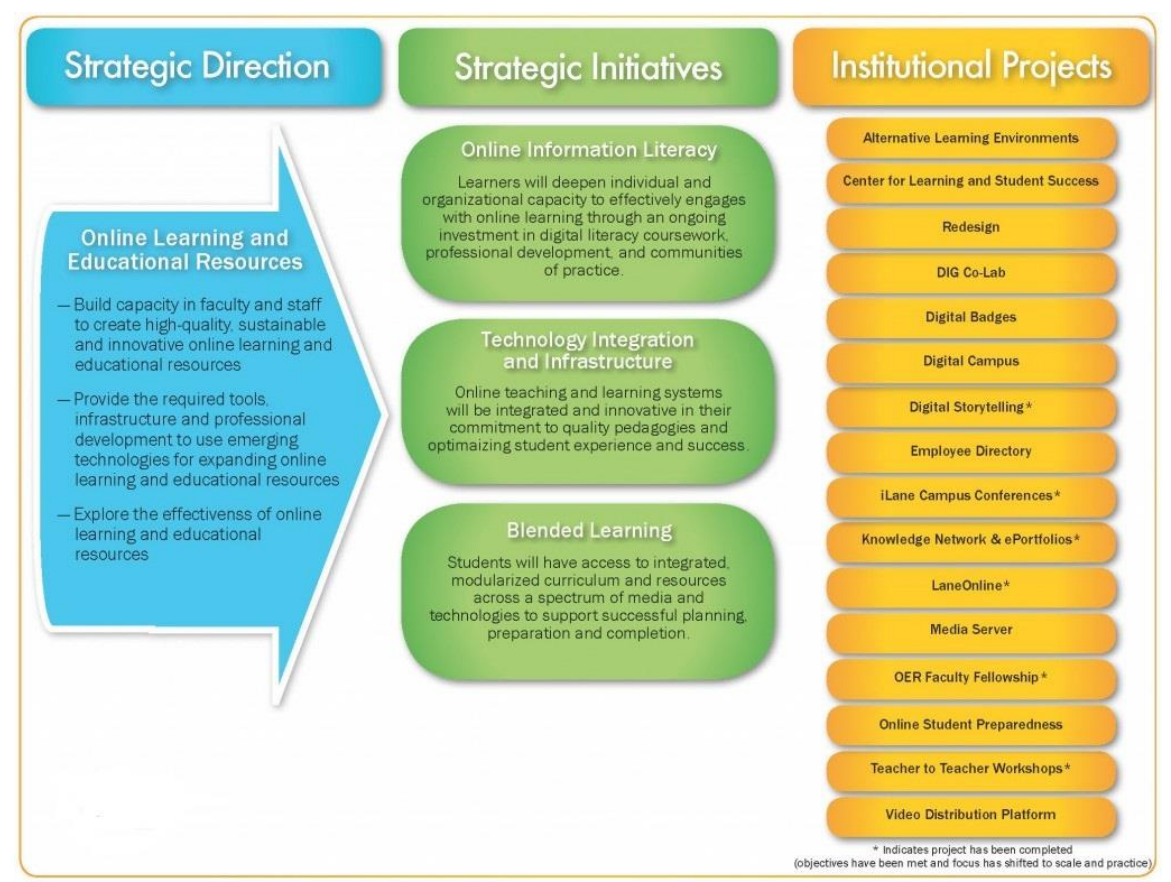

Figure 8. Network Learning Strategy

\section{Current Situation and Countermeasures of English Autonomous Learning}

\subsection{An analysis of College English Autonomous Learning}

The survey sample is from Jinhua Polytechnic undergraduate students in a random 300 people were investigated, including valid questionnaires of 286 , the effective rate was 95\%. The questionnaire uses Cronbach a coefficient to test the internal consistency of each micro scale and the total scale. Cronbach a coefficient was 0.526 , the questionnaire had good reliability. After 2 months interval, the test-retest reliability was $r=0.526$. Therefore, under the information technology environment, the reliability of College 
Students' English autonomous learning ability is better. Survey data show that the purpose of our college students to learn English is mainly concentrated in mastering English skills and parents and teachers under pressure and expectations. The questionnaire is provided with multiple options for the problem, which are learning English in order to master English skills, boys and girls have a ratio of about 70\%, can be seen in students' major objective and teaching purpose of learning English is basically the same, the student satisfaction of the whole learning process increased. At the same time, it shows that the motivation of students learning English comes from internal motivation, and the motivation of learning English in College English Teaching under the information environment has been stimulated.

Table 1. The Purpose of Learning English

\begin{tabular}{|l|l|l|l|l|l|}
\hline objective & $\begin{array}{l}\text { parents and } \\
\text { teacher's } \\
\text { supervision }\end{array}$ & $\begin{array}{l}\text { Mastery of } \\
\text { knowledge }\end{array}$ & Response test & study overseas & Other \\
\hline male & $42 \%$ & $70 \%$ & $34 \%$ & $18 \%$ & $27 \%$ \\
\hline female & $38 \%$ & $73 \%$ & $26 \%$ & $20 \%$ & $31 \%$ \\
\hline
\end{tabular}

The majority of students to develop learning objectives and plans, some students can do well, more than $70 \%$ of the students have been out of the traditional passive learning, making learning plans and goals, in order to have enough time to learn English, arrange their own learning schedule, even without the urge parents and teachers, can active learning. Some of the students will learn the contents, preview, every day after class listening and reading training, in order to improve their English level, make full use of all kinds of training opportunities for classification of learned English knowledge, trying to make themselves are learning content and has some knowledge together.

Table 2. Self-Regulation Ability in English Learning

\begin{tabular}{|c|c|c|c|c|}
\hline Investigation & Never & Sometimes & Often & Always \\
\hline $\begin{array}{c}\text { Persist in } \\
\text { listening and } \\
\text { reading English } \\
\text { after class }\end{array}$ & $7.4 \%$ & $32.5 \%$ & $15.2 \%$ & $8.3 \%$ \\
\hline $\begin{array}{c}\text { Make learning } \\
\text { plans }\end{array}$ & $24.9 \%$ & $50.2 \%$ & $19.3 \%$ & $2.0 \%$ \\
\hline Active learning & $8.1 \%$ & $34.2 \%$ & $56.2 \%$ & $3.8 \%$ \\
\hline $\begin{array}{c}\text { Understand the } \\
\text { purpose of } \\
\text { teaching }\end{array}$ & $21.2 \%$ & $53.7 \%$ & $19.6 \%$ & $8.2 \%$ \\
\hline $\begin{array}{c}\text { Reasonable } \\
\text { arrangement of } \\
\text { learning }\end{array}$ & $13.5 \%$ & $56.2 \%$ & $23.8 \%$ & $10.6 \%$ \\
\hline $\begin{array}{c}\text { Self questioning } \\
\text { and reflection }\end{array}$ & $14.8 \%$ & $60.1 \%$ & $22.0 \%$ & $4.1 \%$ \\
\hline
\end{tabular}

\subsection{Strategies of Autonomous Learning in English}

In the modern educational media technology with multimedia technology and network technology as a symbol of teaching media is the environment, is the organization of teaching information interaction of a group of organic, conditions, information organization adopt network structure, flow and control information is a two-way multilateral, teachers and students are in the receiving and sending status information. In College English class, the teacher's primary role is no longer directly provide language 
information, but in the organization of language information, the creation of language context, communicative needs and stimulate interest in learning, causing learning and exploration activities, actively at the same time, to provide information for the students in the clues necessary to provide the necessary support to help students learn the language and the use of communication. Autonomous Learning under the information environment includes three aspects:

- Autonomous learning is a kind of active learning: I want to learn is based on the students' internal needs for learning, I want to learn is based on external incentives and coercion. The intrinsic needs of students to learn on the one hand for the interest in learning, students have a learning interest, learning activities for him, it is not a burden, but a pleasant experience. The multimedia function based on information technology, provides a game like learning environment, learning materials are rich and colorful, extremely rich, interactive strong hyperlinks and virtual function, can greatly stimulate students' learning, cultivate their strong interest in learning.

- Independent learning is an independent learning: independence is the core quality of autonomous learning, if the initiative for me to learn, then independence for me to learn. Each student has a strong potential and now independent learning ability, at the same time have an independent requirements, have a desire to express their ability to learn independently. Information technology based multimedia computer network because of its vivid presentation of knowledge, so that students are easy to understand the difficulties and focus, ease the difficulty of student learning, so that they can better independent learning. At the same time, the network provides the hyperlink function established closer logical relation between the knowledge points, students can according to their own learning and learning to choose learning content relevant to their learning activities.

- Autonomous learning is a kind of meta cognitive monitoring learning: learning requires students to have conscious awareness and response to learning, learning, learning can do what, how to learn, learning activities, students can determine their own learning goals, make learning plans, choosing learning methods, make preparation for study in the learning activities; and to be able to learn their own learning process, learning behavior, self observation, self reflection and self adjustment. It is an important factor to promote students' autonomous learning to cultivate students' self-awareness and self-monitoring, cultivate their habits, form interest and take responsibility.

\section{Conclusions}

The emerging of new technology and the application in classroom will change the structure and form of classroom. At present, the future design and application of classroom education has gradually become a new field of science and technology, intelligent classroom is an important form of future classroom, one of the important characteristics of intelligence is the future of the classroom, strengthen the research of intelligent classroom will help us to the classroom for new understanding and design, finally construct a training needs and new curriculum reform in a classroom full attention to subjective freedom, harmonious development of new classroom / classroom innovative talents for the future. The effect of students' autonomous learning is influenced more by the design of teachers' courseware and the setting of network courses. At the same time, teachers also help students develop autonomous learning ability, so that English teaching toward individual learning, not limited by time and place of learning. The teacher should not only have profound professional knowledge of English, but also master the means of information technology such as computer and network applications, a variety of effective means and methods to promote students' Autonomous learning. 


\section{References}

[1] C. Krstev, and A. Trtovac, "Teaching Multimedia Documents to LIS Students", The Journal of Academic Librarianship, vol. 40, no. 2, (2014), pp. 152-162.

[2] S. J. Hua and L. hong, "Explore the Effective Use of Multimedia Technology in College Physics Teaching”, Energy Procedia, vol. 17, (2012), pp.1897-1900.

[3] R. A. Sabella, "School counselors perceived importance of counseling technology competencies", Computers in Human Behavior, vol. 26, (2010), pp. 609-617.

[4] N. R. Mastroleo and R. Turrisi, "Examination of post-training supervision of peer counselors in a motivational enhancement intervention to reduce drinking in a sample of heavy-drinking college students", Journal of Substance Abuse Treatment, vol. 39, (2010), pp. 289-297.

[5] Z. Huang and M. Benyoucef, "From e-commerce to social commerce: A close look at design features", Electronic Commerce Research and Applications, vol. 12, no. 4, (2013), pp. 246-259.

[6] C. Zhang and X. Chen, "Use of Multimedia in Gross Infective Pathogen Experimental Teaching", Procedia Engineering, vol. 37, (2012), pp. 64-67.

[7] W. Dai and L. Fan, "Discussion about the Pros and Cons and Recommendations for Multimedia Teaching in Local Vocational Schools", Physics Procedia, vol. 33, (2012), pp. 1144-1148.

[8] R. Khansa, "Teachers' Perceptions toward School Counselors in Selected Private Schools in Lebanon", Procedia - Social and Behavioral Sciences, vol. 185, (2015), pp. 381-387.

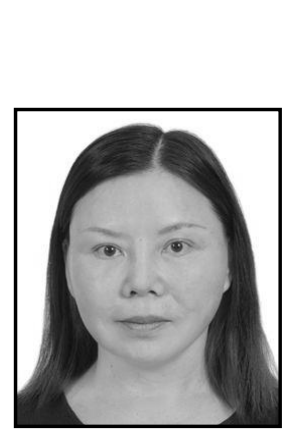

\section{Author}

Wang Pingxiao, 1966.5, Jinhua, Zhejiang, P. R. China, Current position, grades: the lecturer of General Education College, Jinhua Polytechnic, Zhejiang, China. Scientific interest: English teaching and educational reform. Publications: more than ten papers and a textbook published, Experience: She has been teaching in Vocational College for nearly fifteen years and has completed five teaching research projects. 
International Journal of Multimedia and Ubiquitous Engineering Vol.12, No.1 (2017) 